\title{
Om å være for å lære - noen studenters erfaringer med å skrive, tenke og lære
}

\author{
Grete Salicath Halvorsen \\ Hogskolen Innlandet, Norge
}

\begin{abstract}
Artikkelen drøfter forholdet mellom det å skrive, tenke og lære. Jeg har intervjuet Io studenter fra en videreutdanning i veiledning om deres erfaringer med sitt skrivearbeid. Studentene på denne videreutdanningen oppfordres til å ta egne valg med hensyn til skrivesjanger, litteratur med mer.

I undersøkelsen som artikkelen bygger på forteller studentene om hvordan skrivehandlinger og andre handlinger stimulerer tenkningen. Gjennom fortellingene trer tenkningen fram som et kroppslig samspill. Slik får vi en forståelse av betingelsene for dette samspillet, og dermed også av betingelsene for tenkningen og læringen. Disse kan vi knytte til det å være; vår eksistens. Her er det to sentrale begreper: autonomi og anerkjennelse. For studentene er det å ha autonomi viktig, men kanskje er det å anerkjennes som autonome individer viktigere. Videre opplever studentene at anerkjennelse generelt, altså det å bekreftes som den de mener at de er, skaper motivasjon og mestring. Studentene styrkes i sitt selvforhold. Når studentene opplever at meningen skapes gjennom skrivearbeidet, kan det også forstås som anerkjennelse: De får seg selv bekreftet gjennom teksten, og de styrkes i sitt selvforhold.

Læringsperspektivet som meisles ut er dermed følgende: Vi forstår og lærer når vi er, og når vi anerkjennes som den vi er.
\end{abstract}

Nøkkelord: anerkjennelse; autonomi; kunnskapsformer; lære; skrive

\section{INNLEDNING}

Det skriftlige står sentralt i høyere utdanning. Studentene skriver for å vise fram hva de kan og for å bli vurdert, og det å skrive sees på som et pedagogisk virkemiddel. I denne undersøkelsen er det studentens erfaringer med skrivearbeidet som undersøkes. Undersøkelsens spørsmål er følgende: Hvordan opplever og erfarer studentene sitt skrivearbeid, og hvordan kan erfaringene forstås?

Dette er et åpent spørsmål, men det springer jo ut av en tanke; en for-mening eller et annet spørsmål. Det er derfor Gadamer (2007) sier at et spørsmål også er et svar. Og jeg har noen tanker - og spørsmål. Det er dristig å sette dette på begrep. Jeg er opptatt av forholdet mellom det å være i verden og det å forstå. Kanskje kunne jeg brukt ordene eksistens og essens om dette forholdet, men ordene blir for store. Jeg velger å beskrive dette som et forhold mellom form og innhold - i bred forstand. Med form tenker jeg for eksempel på skrivehandlingen, skrivemåten, skriveprosessen og utformingen, og med innhold for eksempel på studentens opplevelse av å ha kommet fram til mening og nye innsikter formidlet i tekst. Undersøkelsens forskningsspørsmål er derfor: I) Betyr formen noe for innholdet? 2) Hvordan kan vi forstå denne sammenhengen mellom form og innhold?

*Författarkontakt: grete.halvorsen@inn.no

Artiklar och reflektioner är kollegialt granskade. Övriga bidragstyper granskas av redaktionen. Se https://hogreutbildning.se ISSN 2000-7558

(C)2021 Grete Salicath Halvorsen. This is an Open Access article distributed under the terms of the Creative Commons Attribution-NonCommercial 4.0 International License (https://creativecommons.org/licenses/by-nc/4.0/), allowing third parties to share their work (copy, distribute, transmit) and to adapt it, under the condition that the authors are given credit, that the work is not used for commercial purposes, and that in the event of reuse or distribution, the terms of this license are made clear.

Citation: Halvorsen, G. S. (2021). "Om à vare for à lare - noen studenters erfaringer med à skrive, tenke og lare», Högre utbildning, 11(2), 58-69. http://dx.doi.org/10.23865/hu.v11.2506 


\section{MIN SKRIVEMÅTE}

Min skrivemåte og uttrykksform kan karakteriseres som essayistisk. Et faglig essay har gjerne en mer åpen, spørrende og personlig form enn artikkelsjangeren. Dette er et bevisst valg. Skrivemåten er prosessuell og refleksiv og er en måte å komme fram til kunnskap på, altså en vitenskapelig metode - en vei å gå. For å sitere meg selv (Grete Halvorsen i: Bech-Karlsen, 2003, s. 60):

Det metodiske ligger i den refleksive bevegelsen; tvilen og vissheten om at alt er i forandring, blir motoren som driver oss til stadig å søke etter ny forståelse. Dialogen er en del av den refleksive bevegelsen. Jeg forsøker å føre en dialog med meg selv, der essayet er den andre stemmen, den kritiske og selvreflekterende stemmen. Etter beste evne snakker jeg med andre skribenter for å prøve å forstå hva de har tenkt. Deres tanker kan kaste nytt lys over mine tanker, eller de kan rett og slett gi lys til noen tanker som ulmer i mørket. Og leseren er turkamerat og samtalepartner fra begynnelse til slutt. Uten disse samtalene, uten bevegelsen, skjer det ingen ny erkjennelse. Og uten disse samtalene, kunne jeg gjøre som jeg ville, jeg kunne dikte fritt og uhemmet. Det kan jeg ikke.

\section{METODE - HVORDAN HAR JEG GÅTT FRAM?}

Intervjuene er gjort våren 20I9. Informantene er studenter på en videreutdanning i veiledning, og de er i sitt fjerde og siste semester. Minimumskravet for opptak på denne videreutdanningen er at en innehar en helse/sosialfaglig bachelorgrad og to års yrkeserfaring.

I studiet vektlegges dynamikken mellom praksiserfaringer og teori, og hvert semester har derfor et krav om Is timer egen veiledningspraksis. Det skriftlige arbeidet har en relativt stor plass, og det undervises i en essayistisk skrivemåte og andre sider ved skrivearbeidet. (NTNU, 20I8)

Studentene velger selv skrivesjanger, og de fleste velger en essayistisk framstillingsform. De velger også problemstilling eller spørsmål for de skriftlige innleveringsarbeidene, og de oppfordres til å finne litteratur som de mener er relevant og spennende. Pensum presenteres som veiledende.

Informasjon om prosjektet ble gitt muntlig til klassen. De fikk også skriftlig informasjon med en samtykkeerklæring. Studentene meldte sin interesse direkte til meg. Ti (av tolv) studenter ønsket å delta. Informantene valgte tid og sted for intervjuet. Det var satt av én time til hvert intervju. De fleste intervjuene var på rundt 45 minutter.

Metodisk og kunnskapsteoretisk er undersøkelsen forankret i en fenomenologisk-hermeneutisk tradisjon. Hva legger jeg i denne tradisjonen? Jeg spør ikke her om «hva noe er», men om hvordan noe framtrer (Bostad, 20I7). Hvordan få noe til å fremtre og hvordan forstå? Jo, gjennom å ta «det» - som her er erfaringer - imot så åpent og forutsetningsløst som mulig. Men dette er vanskelig. For vi har allerede en forståelse. Husserl sa at vi må sette denne forståelsen i parentes, slik at oppmerksomheten kunne rettes fullt og helt mot saken slik den viser seg for hver og en av oss (Zahavi, 2003). Dette fikk han etter hvert en rekke tilsvar på: Vi kan ikke uten videre legge vi til side det vi allerede har forstått; våre for-meninger; vår forforståelse (Gadamer, 2007; Heidegger, 2007). Men vi kan prøve. Og det hjelper å være seg dette bevisst, og å øve på åpenheten. En slik holdning kan, etter mitt skjønn, lede til tilsvarende handlinger. Det er altså ikke mulig her å skille teorier og framgangsmåter. Jeg har ovenfor kort gjort rede for en tenkning om hvordan vi forstår det menneskelige, omtalt som en fenomenologisk-hermeneutisk tradisjon. Tenkningen gir «anvisninger» på hvordan vi bør forholde oss for å forstå det menneskelige. Jeg har også gjort rede for hvordan jeg forstår disse «anvisningene». Dette er å forstå som mine holdninger. Jeg ønsker, og jeg prøver, å la mine holdninger styre mine handlinger. Tanker, holdninger og handlinger henger med andre ord her tett sammen. 
Intensjonen om størst mulig åpenhet viser seg blant i hvor strukturert du vil at intervjusituasjonen skal være. Jeg valgte å legge en intervjuguide til grunn, men ønsket mest mulig åpne intervjuer. Informantene fikk spørsmål om sine erfaringer med å skrive (for å lære), om hvordan de konkret går fram (med et arbeid som skal vurderes), om de hadde tanker om forholdet mellom form, formaliteter og innhold og om hva som fremmer og hemmer i en skriveprosess. Intervjuene er tatt opp og transkribert.

Hvordan forstå erfaringene som fremtrer? Fordi vi hele tiden tolker og forstår, samtidig som vi prøver å være åpne og mottakelige, så er det riktig å forstå arbeidet med å analysere, tolke og skape mening i materialet som en kontinuerlig prosess. Analyse- og tolkningsprosessen kan med andre ord beskrives som en gjennomgående prosess (Brottveit, 20I8b; Nilssen, 20I2).

Hvordan ordne og presentere materialet slik at det gir mening? Brottveit (2018a) skriver at «(m)ed analyseprosessen kommer du fram til funn, mens tolkningsprosessen hjelper deg å skape mening i funnene» (s. IO4). Men hva giør vi - mer konkret? Vi deler opp og identifiserer meningsenheter, altså analyserer, og vi setter enhetene sammen igjen, altså syntetiserer, slik at helheten gir mening. Og, som jeg var inne på ovenfor, så er det ikke tilfeldig hvordan vi setter enhetene sammen. Forståelsen og meningen skapes både ut fra åpenhet og nysgjerrighet (nyfikenhet), men også ut fra noe som vi aner konturene av og som vi forsøker å utvikle.

Det finnes mange beskrivelser av framgangsmåter. Og begrepene som brukes, for eksempel koder og kategorier, brukes litt om hverandre (Brottveit, 20I8b). Det er med andre ord nødvendig å gjøre egne valg i analyse- og tolkningsarbeidet. Første steg i analyseprosessen beskrives ofte som åpen (Brottveit, 20I8b) eller empirinær (Tjora, 2018) koding. Når det gjelder antall steg, og hva stegene skal kalles fram til endelige konklusjoner, er det mange forslag. Dette henger sammen med spørsmålene om når, og hvordan, man bestemme hva noe kan tenkes å være. Selv har jeg valgt å bruke «empirinær koding» om steg én, og «kodegruppering» og «temaer» om steg to og tre. Med empirinær koding gjelder det å komme tett på empirien. Jeg leste datamaterialet med så åpent blikk som mulig, og noterte i margen når noe interessant trådte fram. Her brukte jeg stort sett informantenes egne ord. For eksempel uttrykket «å få lov til», som Eva snakket mye om. Samtidig som jeg forsøkte å være så tett på erfaringene som mulig, skapte hver enkelt kode, og etter hvert hver enkelt kodegruppe, også ideer til temaer: Utrykket «å få lov til» satte for eksempel i gang tanker om autonomi i mer abstrakt forstand. En kodegruppe (få lov til, frihet, fritt, befriende, bestemme selv med mere) utvikler seg til et tema (autonomi) gjennom en dialektisk prosess, der det kontinuerlig søkes etter sammenhenger.

Forståelses- eller kunnskapsprosessen kan også beskrives som induktiv, deduktiv og abduktiv. Mange velger å omtale en undersøkelse som dette som induktiv, fordi den undersøker enkelttilfeller og utvikler generelle innsikter ut fra dette. Jeg mener at det er mer fruktbart å se slike prosesser som et samspill mellom det induktive (det konkrete) og det deduktive (det abstrakte eller andres tanker og teorier). Ved å sette det konkrete og det abstrakte i spill etableres forståelse og kunnskap. En slik framgangsmåte kan karakteriseres som abduktiv (Laursen, 20I7; Peirce \& Gullvåg, 1972), hvilket innebærer at vi befinner oss i en kontinuerlig dialektisk bevegelse mellom det konkrete og det abstrakte, mens vi søker etter og gjetter på, mønstre og sammenhenger (Peirce, 1994).

Jeg har ovenfor beskrevet et tankesett og en arbeidsmåte der forskeren og skribenten, i dette tilfellet meg, er direkte involvert i forståelsesprosessen. Jeg forsøker å forholde meg åpent til det som trer fram (erfaringene), men jeg fortolker og forstår ved det jeg allerede har forstått. En sentral del av det jeg allerede har forstått er andres tanker og teorier. Jeg bruker andres tanker og teorier til å tenke med, og ikke for å framføre logiske bevis. Prosessen er beskrevet som induktiv, 
deduktiv og abduktiv, hvilket kan forstås som å være tett på, skape avstand og å være søkende og nysgjerrig (nyfiken). Jeg har en essayistisk arbeids- og uttrykksform, som jeg anser som en viktig del av forståelsesprosessen. Jeg prøver å holde spørsmålet levende (Gadamer, 2007). «Hva vet jeg?», sa Montaigne, som ikke trodde ikke på den ferdige tanken: «hvis man tilfeldigvis prøver å gripe dens vesen, ville det være som å gripe i vann: jo mer man presser hendene sammen for å fastholde det hvis natur er å flyte fritt omkring, jo mindre ville man få tak i» (1979, s. 49).

Materialet er anonymisert. Navnene er fiktive. Undersøkelsen er godkjent av Norsk senter for forskningsdata.

\section{RESULTAT OG DISKUSJON}

Studentene forteller om opplevelser og erfaringer med å skrive, tenke og lære. Jeg skjelner mellom opplevelser og erfaringer: Jeg forstår opplevelser som kroppslige, nåtidige og intuitive fornemmelser, og erfaringer som mer avklarte og begrepsfestede opplevelser (Gadamer, 2007; Halvorsen, 20II). I dette materialet må det meste karakteriseres som opplevelser. Det som ikke er avklart og begrepsfestet er vanskelig å uttrykke, men det kan fortelles fram, oppleves, erfares, analyseres, tolkes og diskuteres.

Overordnet har jeg samlet funnene i to påstander som åpner for to samtaler. Den ene samtalen dreier seg om form - i bred forstand: kropp, handling, materialitet og romlighet, og den andre om innhold - i bred forstand: anerkjennelsens og autonomiens betydning for forståelse og læring:

I) Skrivehandlingen virker på tenkningen gjennom en kropp som er - i virksomhet $i$ verden.

2) Vi forstår og lærer når vår selv- og virkelighetsforståelse anerkjennes.

\section{Skrivehandlingen virker på tenkningen gjennom en kropp som er - i virksombet $i$ verden}

Hva er tenkning? Hvor sitter tenkningen? Tidligere har tenkningen vært lokalisert til hjernen, og hjernen har på et vis også ofte blitt framstilt som atskilt fra kroppen. Til dels, og svært forenklet, kan vi også si at det å tenke og forstå har vært presentert som en logisk og rasjonell prosess, uavhengig av handlinger og følelser. I dag er dette synet i endring. Man ser mentale prosesser som et samspill mellom hjernen, (resten av) kroppen og omverdenen.

Tenkningen forstås altså som et dialektisk forhold mellom hjernen, kroppen forøvrig og

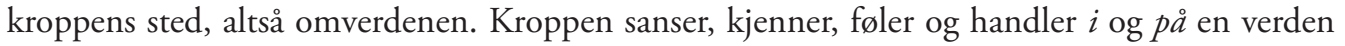
(Merleau-Ponty, 1994; Stern, 2007), og hjernen mottar og forvalter signalene. Her henger alt sammen med alt (Bateson, 2000). Derfor er det så å si umulig å skille tenkningen fra kroppen, og kroppen fra omverdenen. I et forsøk på å konkretisere og tydeliggjøre poengene gjør jeg likevel et forsøk.

Den skrivende og tenkende kroppen

Studentene snakker om skrivearbeidet sitt som en rekke ulike handlinger, og de bruker et aktivt språk. La meg først sette scenen ved hjelp av noen eksempler, før vi gjennom studentenes stemmer forsøker å danne oss et bilde av forholdet mellom å skrive og tenke.

Eva forholder seg til rammene for oppgaven, men hun vil også skrive om det hun er opptatt av: «så da går jeg litt sånn fram og tilbake mellom rammene og hva jeg har lyst til å skrive om da, på en måte». Ida går også. Hun går «først og tenker på det en stund», og når hun har kommet $\mathrm{i}$ gang og «står fast og er drittlei, da går» hun en tur. Kaja setter seg bare «ned og skriver noe, og 
da løsner det». Studentene forteller om stor aktivitet med hensyn til å rydde, stryke, flytte, og gå tilbake eller att og fram (i teksten).

Den skrivende og tenkende kroppen er som vi ser en kropp i virksomhet, der de mentale og fysiske aktivitetene og omverdenen både henger sammen og virker på hverandre.

I en skriveprosess arbeider studentene blant annet med a) litteratur, b) å få tankene ut og ned på papiret, c) selve utformingen eller d) de gjør helt andre ting:

a) Så godt som alle studentene i mitt materiale velger litteratur ut fra interesse og engasjement. De ser på pensum som veiledende. Aida leser det hun «faller litt for». «Der begynner jeg», sier hun. «Da får jeg opp motivasjonen, så kan jeg ta tak i det jeg må ta tak i etterpå.»

b) Studentene tenker, og de blir ofte overrasket fordi tanken ser annerledes ut når den kommer ned på papiret. Beth synes at hun har det ganske klart i hodet, men «i huet virker det annerledes enn det jeg skriver ned». Kaja sier det samme: «jeg trur inni hodet mitt at nå har jeg det klart. Men når jeg leser det jeg har skrevet, så ser jeg jo at det er det ikke.» "Jeg kan ikke sitte og tenke ferdig setninger sånn inne i hodet mitt, og skrive de ned», sier Ida.

De opplever også at tanken er flyktig. Åsta må forte seg å skrive ned tanken, for «plutselig kommer jeg på noe veldig lurt og så kan det bli borte». Også Kaja snakker om dette glimtet av en «tanke, eller kanskje en følelse? Det er noe med at jeg rekker å skrive ned det jeg tenker på, det jeg føler at ...».

Skriving «utvikler tankekraften», sier Moi (2019, s. 2I), og studentene oppdager at tankene kommer og foredles med skrivingen: «De bare kommer mens jeg skriver, og det er vel fordi jeg tenker mens jeg skriver», sier Kaja.

c) Med utforming tenker jeg blant annet på det å arbeide grundig med språk, tegn, grammatikk og sammenheng. "Å lage setninger er å tenke tanker», sier Johansen (2009, s. 19), og han fortsetter: «Å lage ufullstendige, løst sammenhengende setninger, er å tenke tanker av samme slaget.» Men å skrive tanken ut og ned er en god begynnelse. Når tanken er skrevet ned, «har det åpnet seg en avstand mellom den og meg: Nå kan jeg gi meg til å vurdere den kritisk for alvor» (Johansen, 2009, s. 23). Tanken blir med andre ord klarere når vi arbeider med det språklige uttrykket, tegnsettingen, grammatikken og sammenhengen.

Dette erfarer også studentene: «Og de gode opplevelsene da. Når du driver og rydder, og du går tilbake og leser, og så ser du plutselig sammenhenger som du ikke så før, eller du ser at du kan kutte ned på et avsnitt, eller du kan flytte det slik at det gir bedre mening eller mer flyt, og da ... da jobber vel huet da?», spør Egil. Studentene forteller at de rydder, klipper, flytter og leser, og at de ser nytten i dette. Aida «klipper, flytter og setter sammen, sånn at teksten får en naturlig flyt». Ida «rydder unna ord som ikke har noen bærende betydning for det» hun vil si. Og Åsta går «att og fram i teksten, så leser jeg oppatt, tenker nei, dette blir feil! Så går jeg tilbake igjen, retter litt, - og sånn holder jeg på. Da blir det klarere.»

Studentene erfarer og forstår at selve skrivehandlingen stimulerer tenkningen, og at lese-, skrive- og tankevirksomheten arbeider sammen og virker på hverandre.

d) Studentene oppdager også at de tenker godt når de ikke arbeider direkte med tekstens form og innhold, men gjør helt andre ting. Ida får mange nye tanker om oppgaven når hun arbeider med den, «men det nye kan jeg like gjerne komme på når jeg går til jobb». 
Hanne forteller at hun ofte kommer på noe lurt når hun «støvsuger eller klipper plenen, og da må jeg forte meg å skrive det ned». «Jeg tenker når jeg skriver», sier Åse, «men jeg tenker egentlig mye ellers også - når jeg gjør husarbeid og går turer og sånn». Hun tenker egentlig på eksamensoppgaven gjennom hele semesteret. Det er en fordel, synes Åse, for når «jeg begynner å skrive da har jeg bearbeida masse, mens jeg har drevet med andre ting. Det er da jeg er mest kreativ - det er når jeg driver med noe.»

Studentene oppdager at både det å drive med noe, og å drive med noe annet enn skrivearbeidet, driver tenkningen framover, og de synes å ane at ordløse, kroppslige opplevelser kan fanges og avgrenses gjennom ordene.

Studentenes opplevelser og erfaringer kan forstås i lys av Aristoteles' (1999) kunnskapsperspektiv. Aristoteles skiller mellom teoretiske, produktive og praktiske virksomheter, og til disse hører kunnskapsformene viten (episteme), kunnen (techne) og klokskap (fronesis). Viten dreier seg om det som ikke kan være annerledes; det eksakte; det som er sikkert og kan bevises, mens kunnen og klokskap dreier seg om handlinger og ferdigheter, det som ikke er eksakt og som må overveies. Studentene forteller at de utvikler kunnskap når det teoretiske, produktive og praktiske er i spill og i samspill. Aristoteles' tanker må forstås som en modell - en forenkling av virkeligheten, og skillet mellom virksomhetene er ikke et absolutt skille, men et tenkt skille. For også Aristoteles mener at «alt henger sammen med alt». Noe han for eksempel utrykker når han viser til «det krumme og det uthulede ved sirkelens omkrets» (Aristoteles, 1999, s. 17). Studentene forteller at de tenker når de er i virksomhet. Jeg har også pekt på at de mentale og de fysiske aktivitetene ikke kan skilles fra hverandre. Slik sett kan vi si at kroppen tenker. Og den tenker mens den er i virksomhet $-i$ verden et sted.

Kroppen er i verden et sted

Studentene er virksomme i, og forholder seg til en romlig og materiell verden. De befinner seg alltid i en bestemt tid, på et bestemt sted, og de skriver for eksempel på og med noe, leser i og på noe og utvikler systemer for å ordne tekst og tanker.

Åsta har sitt eget system for forelesningsnotater: «Jeg har jo vært til stede på alle forelesninger og skriver og noterer. Jeg har jo boka mi med der. Ja, jeg har jo én bok for hvert semester, og der ligger de - forelesningene etter dato, hvem som har forelest, og ...». "Jeg bruker mobiltelefonen mye», sier Egil. «Jeg skriver notatater og ideer i den.» "Jeg har alltid blokka ved siden av meg. Jeg noterer, men ikke mye. Jeg noterer det som jeg synes er essensen for meg. Det er det samme når jeg sitter i forelesning: Jeg skriver ned det som er viktig for meg», sier Ida.

Kaja synes hun tenker bedre når hun skriver for hånd. "Jeg føler liksom at det blir lettere. Når jeg skriver på pc eller mobilen, så får jeg ikke til å tenke like bra.» Hun har sitt system når hun leser faglitteratur: «Ja, i stedet for å markere med tusj da, så skriver jeg det - i en bok da. Jeg skriver det som er viktig for meg.» Og Hedda har sitt system: «Når jeg begynner å skrive selve oppgaven bruker jeg pc, men stikkord og sånne ting som jeg må huske - da bruker jeg penn og papir. Litt gammeldags kanskje? Og når jeg skal lese igjennom oppgaven for korrektur og sånn, da skriver jeg den alltid ut. Da må jeg ha papir. Jeg synes ikke jeg får den gode oversikten når jeg leser på pc-en.»

Åse trenger også noe håndfast, og hun synes det hjelper å se tankene sine: «Jeg bruker jo denne korktavla jeg, vet du. Og i fjor hadde jeg den der Grandiosa-pizzaen, og laget en oppslagstavle av den. Så den der korktavla har jeg hele tiden med meg; der har jeg problemstillingen og andre ting. Da holder jeg den røde tråden.» 

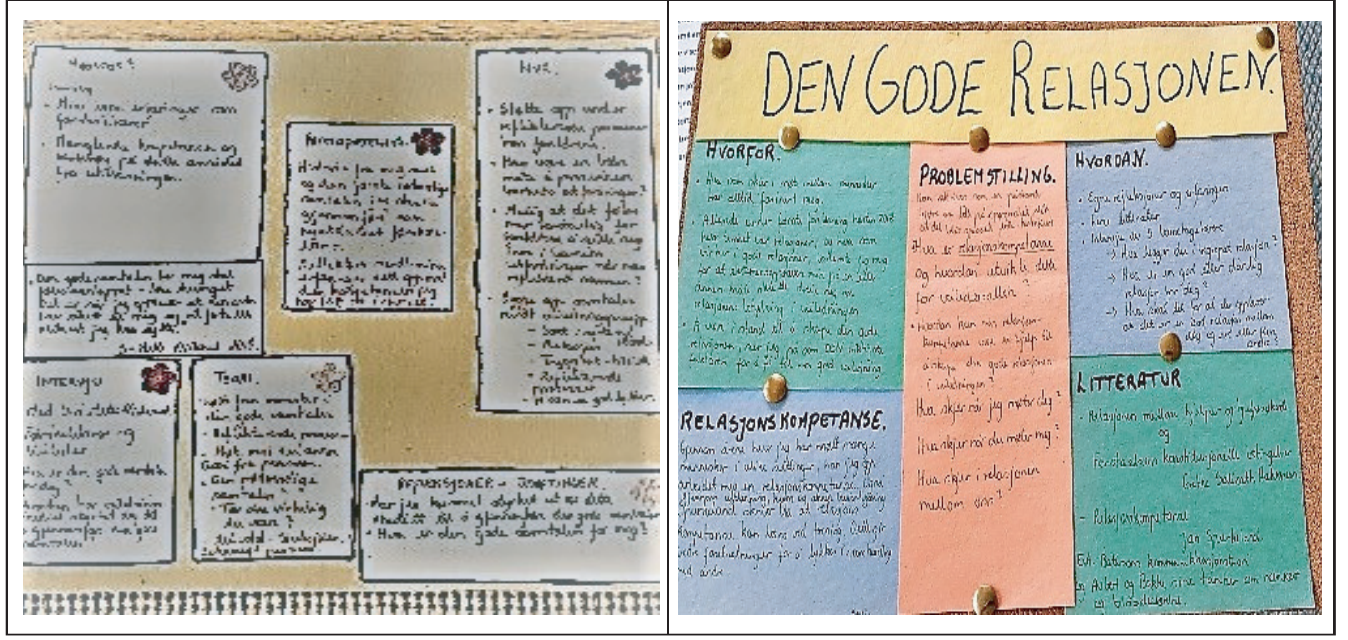

Åses korktavle og Grandiosa-tavle

Studentenes fortellinger viser oss hvordan vi forholder oss til, og virker på, omverdenen, og hvordan den virker på oss. «Når jeg kan sitte og skrive litt så får jeg det mere inn», sier Åsta. Kaja setter seg «på et rolig sted, på loftstua for eksempel, med bare blokka og penn. Etter en stund kan jeg gå tilbake til pc-en og skrive litt.» «Altså - det ser jo ikke ut der jeg sitter og skriver», sier Ida. «Jeg skriver, og så har jeg bøker og forelesningsnotatene min, kladdeark, ting som jeg etter hvert har tatt med meg fra jobben som jeg tenker kan brukes. Det ser ut som et kaos. Men alt er der, og jeg vet det. Og så kan det være at det dukker opp noen henvisninger i en tekst, eller på et ark, som jeg forfølger. Og jeg setter sånne lapper inn i bøkene eller artiklene: Dette må jeg huske til jeg skal skrive det og det.» Egil har en travel hverdag med full jobb og tre små barn. Han tar natta til hjelp når han skal skrive. Tid er et viktig element, men «så er det jo litt sånn andre ting: rommet du sitter $i$, om du har mat i magen, og ... gjerne fyr i ovnen. Ja, at man kan ha det hyggelig når man sitter og skriver da! Det er viktig for meg.»

Studentene opplever både at det å lytte «til de stemmene som vi nesten ikke hører i oss, gir [det] oss nye muligheter til å tenke» (Lie, 20I2, s. 29), og at vi hører disse stemmene best når vi tar hensyn til hvor vi er og hvordan vi har det. De oppdager også at de må flytte på seg for å få nye perspektiver og nye tanker (Lie, 20I2; Meløe, 1985).

Jeg har så langt forsøkt å vise at vår omverden virker på skrive- og tenkehandlingene. Men hva med teksten - kan den også forstås som en del den verdenen som omgir oss?

\section{Teksten}

Studentene forholder seg til teksten som noe materielt som skal ha en form, og de opplever eller erfarer at form og innhold virker på hverandre. «Jeg tenker at alt er en komposisjon, og da får vi ikke skilt form og innhold», sier Eva. Åsta er opptatt av å kjenne på «om det er godt å lese. Ja, for det skal danse litt på linjen på en måte da.» Egil er også opptatt av «estetikken». Han vil gjerne «gjøre det litt fint for den som leser». Og det å tenke på form og estetikk, spør han, har vel «også noe å gjøre med arbeidsgleden da? Det å bare ramse opp noe fra noen bøker, det kan jo ikke gi noen glede til de som leser heller?» Katinka snakker om «å innrede en oppgave». Og som sagt: Det ryddes mye. «Det å rydde i teksten, er kanskje som å rydde i huset?», spør Hedda. Når vi rydder, finner vi mye vi ikke har bruk for. Ida har mye hun vil ha bort. Hun er opptatt av «disse 
orda som ikke har noen betydning som vi kanskje slenger på for å fylle opp. For eksempel at jeg er veldig ... interessert. Hva er det der 'veldig'? Det kan fort bli veldig mye veldig.»

Johansen (2009, s. I4, I5) har omsorg for uttrykket, men det er primært for å komme til nye innsikter, sier han. Studentene har også omsorg for uttrykket. Først for uttrykkets skyld, men de oppdager snart at de gjennom denne omsorgen også når fram til nye og egne innsikter.

Teksten skal ikke bare ha en form. Den tar form, og den er form, underveis i skrivearbeidet. Den oppfattes konkret. Den har en begynnelse og en slutt - bokstavelig talt. Hvor begynner for eksempel studentene når de tar fram teksten? Hedda begynner på begynnelsen: «Teksten begynner jo øverst», sier hun og ler litt, «og jeg skriver nedover. Jeg bruker jo mye tid på å gå igjennom teksten, men jeg vet jo at for hver gang så blir saken klarere.» Og Kaja begynner også "på toppen», og hun gjør det "for å få tråden eller for å finne tråden.»

Så godt som alle informantene ser verdien av å jobbe med form for å få et meningsfylt og godt innhold. Det handler om å gjøre det enkelt, men ikke enklere (Moi, 2019, s. 22). Og det handler om å legge fram det vi ser - både stoffet og vår egen forståelse av det - så klart som mulig (Moi, 2019, s. 22). Men en tekst er ikke bare innhold, sier Moi, med referanse til Wittgenstein og Cavell, det er også en (tale-)handling (Moi, 20I9, s. 22). I en slik (tale-)handling gir vi oss til kjenne. Vi fester tankene til papiret for å dele de med andre, og slik setter vi oss selv og vår eksistens i spill og på spill. Det å gi seg til kjenne er også - med Løgstrups ord (2000) - å våge seg fram i håp om å bli imøtekommet. Med imøtekommenhet mener ikke Løgstrup at den møtende skal være enig eller rose, men at hun eller han forholder seg til saken og tar den på alvor. Dette kan også beskrives med ordet anerkjennelse.

\section{Vi forstår og larer når vår selv- og virkelighetsforståelse anerkjennes}

Forholdet mellom anerkjennelse og læring er både komplekst og komplisert. Jeg skal her antyde en kobling mellom autonomi, anerkjennelse og læring, og se studentenes erfaringer i lys av dette.

Studentene snakker mye om selvbestemmelse. Tanken om det frie og autonome mennesket står høyt i kurs i vår vestlige kultur. Vetlesen (200I) tar likevel til orde for at autonomi er underordnet vår eksistensielle avhengighet. Det «å være menneske innebærer - fra fødsel til død - å befinne seg i avhengighet til andre» (Vetlesen, 200I, s. 37). Og avhengigheten er en ikke-valgt struktur ved tilværelsen, hevder Vetlesen (200I, s. 37), i motsetning til autonomi, som er en verdi og et mål vi i varierende grad ønsker å nå. Anerkjennelse, forstått som det å få bekreftet seg selv og sin virkelighetsforståelse, oppfatter jeg som en del av vår gjensidige avhengighet. Vi blir til og bygger vår identitet gjennom hverandre. Samtidig kan vi ikke snakke om identitet uten å tenke variasjoner av et avgrenset og autonomt selv. Autonomi er viktig for vårt selvforhold; vår identitet, men autonomi må forstås innenfor rammen av anerkjennelse som en grunnleggende livsbetingelse.

Honneths anerkjennelsesteori bygger på Hegels tanker om intersubjektivitet og identitet (Honneth, 2019). Identiteten (selvforholdet) deler Honneth inn i selvtillit, selvverd og selvrespekt, som oppnås henholdsvis gjennom anerkjennelse i nære relasjoner, det borgerlige samfunn og staten (Honneth, 2006a). Selvtilliten er identitetens grunnmur og forutsetningen for alle intersubjektive forhold. Selvverd i form av sosial aktelse oppnås i de kulturelle, politiske og arbeidsmessige sammenhenger og selvrespekten bygger vi opp gjennom den allmenne aktelse som er gitt i form av rettigheter (Honneth, 2006a).

La oss se hvordan autonomi, anerkjennelse og læring og forholdet mellom disse fenomenene konkret trer fram innenfor noen sentrale, didaktiske områder. 
Skrivemåten

Studentene på dette studiet oppfordres til en essayistisk skrivemåte. Essayet, sier Beck-Karlsen (2003), er åpent, søkende, sanselig og reflekterende. Alle informantene snakker om friheten de opplever at denne formen gir. Det at de kan skrive ut fra interesse og engasjement er av stor betydning. Det gir skriveglede og arbeidslyst. De opplever også at de lærer mer når de arbeider i denne sjangeren, enn i en mer tradisjonell sjanger. I det aktuelle semesteret hadde imidlertid studentene én oppgave med noen konkrete spørsmål som skulle besvares. «Den oppgaven var jo litt mer styrt enn vi har vært vant til,» sier Eva, «og det er jo ikke jeg så fan av. Men så fant jeg en måte å snakke om det jeg ville likevel.» Eva er opptatt av dette med autonomi: «Det at jeg får lov til å skrive om det som opptar meg; mine interesser, har vært viktig. Det handler vel om at vi får lov til å bruke oss sjøl, og at vi får lov til si hva vi mener. Det er da jeg får brukt huet mitt. Det er noe med å få lov til å utforske, framfor å ha fasiten.» Hun liker å skrive, sier hun. Men det er nå, slik var det ikke før? «Nei, før gjorde jeg det ikke så bra. Det føltes som at jeg hele tiden var ute og søkte etter alle kriteriene, og da klarte jeg ikke å fokusere innover på hva jeg har lyst til, hva mine interesser er, hva jeg synes er spennende sjøl». Åsta liker også denne skrivemåten. Det er «veldig allright», sier hun, «men det er litt uvant. Plutselig var det lov å si jeg. Det er litt mer mitt eget». Egil synes det er «veldig befriende og godt» å skrive på denne måten. «Jeg liker at min stemme får komme fram», sier han. Skrivemåten gir studentene mulighet til å arbeide med, og reflektere over, egne og andres erfaringer og forståelser, slik arbeider de også med egen selvforståelse og eget selvforhold.

\section{Litteraturvalg}

Studentene gjør - i ulik grad - selvstendige valg av litteratur. Det foreligger et pensum, og de fleste velger bevisst noe ut og noe inn. De leser ut fra interesse. Eva forteller at hun «kikker igjennom pensumlista, så ser jeg meg ut det jeg synes er spesielt interessant, og så starter jeg der. Jeg gjorde det ikke sånn før. Da begynte jeg på første siden og leste meg gjennom pensum. Det var det som var rett.» "Jeg tror at vi lærer mer av egne refleksjoner, enn å ha et veldig fokus på pensum og sånn», sier Egil. «Før var det sånn at jeg skulle vise at jeg hadde lest. Det var hovedpoenget. Det lærer ikke jeg noe særlig av. Jeg liker å velge sjøl det jeg skal lese! Og det synes jeg at det er rom for på dette studiet her da.» Åse synes «hun har vært ganske flink til å velge ut litteratur som har vært riktig for henne.» Hun peker på forholdet mellom praksis og teori: «Det har gjort det enklere for meg å knytte det jeg skriver om, til relevant teori.» Hun har - i dette tilfellet - en virkelighet som hun forsøker å forstå ved hjelp av teori, altså andres tanker, og hun tar ansvar for hvilke tanker hun synes best belyser denne virkeligheten. Hun sier videre at hun «liker å gå i dybden. Det er ikke noe vits i å ha massevis av litteratur bare for å imponere. Det virker helt motsatt. Ta heller å velg ut noe. Jeg har vært ganske trygg på meg sjøl nå det siste året: Jeg skriver om det jeg liker å skrive om, for det blir ekte. Jeg skriver om noe som er interessant for meg, noe som betyr noe for meg.»

Når omverdenen anerkjenner vår selv- og virkelighetsforståelse, for eksempel forståelsen av oss selv som autonome, opplever vi oss som hele og slik styrkes vi i vårt selvforhold.

Prosessen

«Det er jo en prosess», sier Eva, «min prosess! Og det er morsomt!» Hva er det som er morsomt? «Ja, det er jo det å utforske temaet og å lære mens jeg skriver. Og også det å få sammenheng mellom teori, egne tanker og fortellingen fra praksis. Og å finne riktige referanser, og noe som jeg føler skaper resonans i meg. Jeg er opptatt av å opptre kongruent i det store og hele - også 
i skriveprosessen.» Beth har alltid vært usikker på det å gi seg til kjenne - så vel muntlig som skriftlig: «Jeg skulle både overveie og veie orda før jeg sa noe, eller før jeg turte å si noe. Men nå er det blitt bedre.» «Det er noe med det å formidle», sier Katinka. «Det er en slags frihetsfølelse. Jeg blir liksom bedre kjent med meg selv. Det er jo det at jeg har fătt fram poenget. Da blir jeg glad. Tenk at jeg fikk det til.» «Og så til slutt så begynner jeg liksom å eie litt av teksten da, - ja, at den på en måte setter seg litt da», sier Aida.

Aida kjenner at teksten blir en del av henne, og at hun har råderetten over den. Katinka synes hun blir bedre kjent med seg selv, og føler seg fri når hun formidler sine tanker. Beth kjenner at hun er blitt modigere til å stå fram som seg selv. Eva vil at skrivearbeidet i alle sine fasetter skal skape resonans hos henne. Det hun gjør, og det hun skaper, må samsvare med den hun mener at hun er. Hun vil være et kongruent menneske, eller med et annet ord: et integrert menneske. Ordet integrert kommer fra det latinske ordet integrare, som på norsk kan forstås som å gjøre hel.

Når uklare tanker - gjennom skrivehandlingene - blir klarere, mer håndfaste og gjenkjennelige og slik også bekreftende, da styrkes vi vel også i vårt selvforhold? La oss se litt mer på dette. Dette som kan forstås som møtet mellom skriver (eller leser) og tekst. Det er et møte der forståelse skapes, og der det åpnes et rom for anerkjennelse. I dette perspektivet kommer leserens subjektivitet i sentrum (Fauskevåg, 20I6). Vi skaper mening gjennom åpenhet og refleksjon. $\mathrm{Og}$ gjennom åpenhet for så vel tekst som en selv, kan vi etablere bånd mellom det vi er fortrolige med, det kjente, og det vi ikke er fortrolige med, det ukjente.

«Å forstå en tekst», sier Fauskevåg, «handler altså om aktivt skape, og ikke bare analytisk prosessere, tekstens mening» (Fauskevåg, 20I6, s. 2I). Å forstå en tekst, eller et fenomen og seg selv i forhold til fenomenet, handler om å aktivt skape mening.

Studentene opplever at de skaper mening blant annet gjennom strevet med å få tankene sine ut og ned på papiret. Når tanken har tatt form og foreligger på papiret, kjenner de igjen tanken, og de opplever at teksten bekrefter deres selv- og virkelighetsforståelse. Slik får de styrket sin identitet og integritet.

Meningene våre har altså en normativ dimensjon. Det er vi - i møter med de andre (direkte eller gjennom for eksempel tekst) - som gir tingen eller fenomenet mening. Det å skape og å gi mening styrker vårt selvforhold, og det forplikter. Vi anerkjenner gjennom å ta stilling både til egne og andres tanker. Fauskevåg skiller mellom meningens subjektive, individuelle og reseptive dimensjon. Om den subjektive dimensjonen skriver han at «(d)et andre mennesket blir et normativt referansepunkt som man forstår seg selv og virkeligheten ut fra» (Fauskevåg, 20I6, s. 27). Den individuelle dimensjonen innebærer imidlertid å ta stilling til referansepunktet: En må anse den andres perspektiv «(...) som gyldig for en selv» (Fauskevåg, 20I6, s. 27). Mening i et anerkjennelsesperspektiv har en ytterligere dimensjon som Fauskevåg kaller reseptiv og mottakelighet, og som jeg ovenfor har omtalt som åpenhet. Vi forstår ved å kjenne oss igjen, slik får vi oss selv bekreftet. Vi forstår gjennom å stå ved det vi forstår: Vi anser det vi deler med den andre som gyldig. Og hele forståelsesakten forutsetter at vi er mottakelige. I dette perspektivet kan vi også trekke inn Gadamers stemme. Han skriver om å gi den andre autoritet. Men da forstått som en anerkjennelses- og erkjennelsesakt, og ikke som underkastelse og avkall på fornuft (Gadamer, 2007, s. 266). Gadamer mener at vi må ha tillit til, og erkjenne at andre kan vite bedre, og vi må slippe denne tilliten til gjennom åpenhet for den andres uttrykk og vår vilje til å forstå (Halvorsen, 20II). Åpenhet overfor andres meninger (her uttrykt i skrift som tekst) handler om å «la teksten virke tilbake på en selv» (Fauskevåg, 20I6, s. 30), og ta stilling til virkningen. 


\section{EN KONKLUSJON - SÅ LANGT}

Jeg stilte følgende overordnede spørsmål: Hvordan opplever og erfarer studentene sitt skrivearbeid? Studentene jeg snakket med fortalte om sine opplevelser og de delte sine tanker om hva som fremmer og hemmer skriveprosessen. De snakket blant annet om hvor de sitter og skriver, hvordan de skriver, hva de skriver på og hvordan de har det mens de skriver, og de beskrev hvordan disse (og andre) faktorer virket på skrive- og tenkeprosessene.

Den andre delen av mitt overordnede spørsmål var: Hvordan kan studentenes erfaringer forstås? Spørsmålet her ble avgrenset av ytterligere to spørsmål: I) Betyr formen (forstått som skrivehandlingen, skrivemåten, skriveprosessen og utformingen) noe for innholdet (forstått som det å skape mening og nye innsikter)? 2) Hvordan kan vi forstå denne sammenhengen mellom form og innhold? Spørsmålene jeg stiller og svarene jeg (foreløpig) gir, er et resultat av samtaler jeg har hatt med andre som har tenkt tanker rundt disse, og tilgrensende, spørsmål.

Erfaringene synes å vise at skrivehandlingen, skrivemåten, prosessen og utforming bidrar til å skape mening og forståelse. Erfaringene gir grunnlag for å forstå det å skrive og tenke som et kroppslig samspill: Å skrive og tenke handler om en kropp som er - i virksomhet $i$ verden.

Videre har jeg pekt på sammenhengen mellom det å skrive, tenke og lære og vårt selvforhold: Studentene er opptatt av å ha autonomi i skrive- og læreprosessene. Slik bekreftes de som selvstendige individer med rettigheter, og de styrkes i sitt selvforhold.

Studentenes erfaringer viser altså at det å skrive hjelper oss å tenke tankene. I forlengelsen av dette perspektivet tar jeg til orde for å forstå det som skjer når tankene får form, materialiseres på papiret og mening skapes, som anerkjennelse: Studentene får bekreftet seg selv og sine virkelighetsforståelser, og de styrkes i sitt selvforhold.

Studentene har fortalt om styrket selvtillit, selvverd og selvrespekt - og om gleden ved å skrive og lære. Men det å ha autonomi betyr ikke å være alene. Fellesskapet har ikke vært tema for denne artikkelen, men kanskje skinner det igjennom som en viktig faktor for studentenes læring og læreglede. Det å forstå og lære handler om at selvstendige individer aktivt skaper mening - sammen. Å lære er med andre ord aktive, intersubjektive prosesser.

\section{FORFATTERPRESENTASJON}

Grete Salicath Halvorsen er førsteamanuensis ved Høgskolen Innlandet, Institutt for sosialvitenskap og veiledning. Hun er utdannet sosionom og har praksis fra blant annet kriminalomsorg og voksenpsykiatri. Hun avla sin doktorgrad i 201 ved Universitetet i Nordland, Senter for praktisk kunnskap, med avhandlingen Relasjonen mellom hjelper og hjelpesøkende. En studie $i$ forståelsens og anerkjennelsens betingelser og muligheter.

\section{REFERANSER}

Aristoteles. (1999). Ethica Nicomachea. Gyldendal.

Bateson, G. (2000). Steps to an ecology of mind. University of Chicago Press.

Bech-Karlsen, J. (2003). Gode fagtekster: essayskriving for begynnere. Universitetsforlaget.

Bostad, I. (2017). A se seg spørrende omkring: Introduksjon til en ny pedagogisk filosofi. Gyldendal Akademisk.

Brottveit, G. (20I8a). Kvalitative forskningsmetoder. I G. Brottveit (Red.), Vitenskapsteori og kvalitative forskningsmetoder (s. 84-107). Gyldendal Akademisk.

Brottveit, G. (Red.). (2018b). Vitenskapsteori og kvalitative forskningsmetoder: om å arbeide forskningsrelatert. Gyldendal Akademisk.

Fauskevåg, O. (20I6). Lesing som anerkjennelse - den manglende dimensjonen i PISAs begrep om leseferdighet. Studier i Pedagogisk Filosofi, 5(I), I8-39. https://doi.org/I0.7I46/spf.v5ir.23245

Gadamer, H.-G. (2007). Sandhed og metode: grundtrak af en filosofisk hermeneutik. Academica. 
Halvorsen, G. S. (20II). Relasjonen mellom hjelper og hjelpesøkende. Universitetet i Nordland.

Heidegger, M. (2007). Veren og tid. Bokklubben.

Honneth, A. (2006a). Kamp om anerkendelse: Sociale konflikters moralske grammatik. Hans Reitzels forl.

Honneth, A. (2019). Tingliggjøring og anerkjennelse: et nytt blikk på et gammelt begrep. Cappelen Damm Akademisk.

Johansen, A. (2009). Skriv! Håndverk i sakprosa. Spartacus.

Laursen, M. H. (20I7). Abduktiv undervisning og laring. Hans Reitzel.

Lie, S. (20I2). Slipp ordene løs! Skriveprosess og fagtekster. Tapir akademisk.

Løgstrup, K. E. (2000). Den etiske fordring. Cappelen.

Meløe, J. (1985). Notater i vitenskapsteori: Til gruppene i humaniora og samfunnsvitenskap med fiskerifag. Universitetet i Tromsø.

Merleau-Ponty, M. (1994). Kroppens fenomenologi. Pax.

Moi, T. (2019). Å skrive er å tenke. I K. Isaksen \& H. P. Blad (Red.), Min metode: Om sakprosaskriving (I. utg., s. I5-23). Cappelen Damm.

Montaigne, M. d., Gide, A. \& Aarnes, A. (1979). Utvalg. Aschehoug.

Nilssen, V. L. (2012). Analyse i kvalitative studier: den skrivende forskeren. Universitetsforlaget.

NTNU. (2018). Studieguide for videreutdanning i Tverrfaglig veiledning, studiearret 2018-2019. NTNU.

Peirce, C. S. (1994). Semiotik og pragmatisme. Gyldendal.

Peirce, C. S. \& Gullvåg, I. (1972). Charles Sanders Peirce. Pax.

Ruyter, K. W. \& Vetlesen, A. J. (200I). Omsorgens tvetydighet: Egenart, historie og praksis. Gyldendal Akademisk.

Stern, D. N. (2007). Her og nå. Abstrakt forlag.

Tjora, A. H. (2018). Viten skapt: Kvalitativ analyse og teoriutvikling. Cappelen Damm Akademisk.

Vetlesen, A. J. (200I). Omsorg - mellom avhengighet og autonomi. I Omsorgens tvetydighet: egenart, historie og praksis (Bd. I, s. 27-40). Gyldendal Akademisk.

Zahavi, D. (2003). Fonomenologi. Roskilde Universitetsforlag. 